\title{
Globális trendek és kockázatok a 21. században - a második évtized
}

A 21. század elejétöl növekedett azon tanulmányok és elemzések száma, amelyek a globális világ közép- és hosszú távú folyamatait és a velük együtt járó kockázatokat mutatták be. Közülük is kiemelkedik a washingtoni székhellyel müködő National Intelligence Council négy-öt évenként Global Trends címmel megjelenő tanulmánya és a davosi Világgazdasági Fórum évente sorra kerülő találkozói előtt publikált Global Risks Report. Ez a tanulmány két részben áttekintést ad az elmúlt két évtized során a fenti forrásokban közreadott gondolatokról és érvekröl, és megkísérli elhelyezni az ismertetett folyamatokat a nemzetközi kapcsolatok elméletének kontextusában. Az első rész elsősorban a globális trendekre koncentrált, míg a jelen második rész a trendek mellett részletesebben foglalkozik a velük járó kockázatokkal is. Mint azt e források alapján is láthatjuk, a második évtizedben készített prognózisok az előző évtizedben leirt trendek folytatását jelezték, ugyanakkor az újabb fejlemények figyelembevételével új szempontokkal egészitették ki azokat. A második évtizedben megfigyelhető trendek fó tartalmát a gazdaság, a technológia, a klímaváltozás, a demográfia, a társadalom, a kormányzás és a konfliktusok területén tapasztalható új jelenségek képezték. A globális trendek mellett a tanulmány második része közelebbről is megvizsgálja a globális trendekkel összefüggő globális kockázatokat és azok összefüggéseit és potenciális hatásait. A 2008 októberi globális pénzügyi válságot követő években a gazdasági növekedés fellendülésének bizonytalanságai domináltak a kockázati tényezők között. Az évtized közepétől a szakértői közvélemény figyelme fokozatosan a klímaváltozás és a kapcsolódó következmények felé fordult. Az évtized végére mind a kockázatok bekövetkezésének valószínüsége mind a potenciális romboló hatás nagysága tekintetében a klímaváltozással kapcsolatos kockázatok kerültek a vezető helyre. Az információs rendszerek elleni támadásokkal összefüggő kockázatok a klímaváltozás után a második helyet foglalták el a 2019. évi davosi fórumon. A fokozatosan növekvő közép- és hosszú távú kockázatok között indokolt megemlíteni a növekvő vagyoni és jövedelmi különbségeket, amelyeket a szakértők a társadalmi polarizáció és politikai ellentétek fö okaként értékelnek.

Kulcsszavak: ellenálló képesség, kockázatok valószínüsége, kockázatok összekapcsolódása, igazság utáni kor, trilemma

\section{Matus János: Global Trends and Risks in the 21st Century - The Second Decade}

From the beginning of the 21st century an increasing number of studies analysed the short and long-term processes and the evolving risks of the global world. One of the outstanding examples is the paper published every four-five years by the National Intelligence Council, a Washington-based organisation, under the title Global Trends. The other prestigious paper is the Global Risks Report by the World Economic Forum, published every year before the Davos Summit. This study summarises the ideas and arguments formulated in the documents published during the two previous decades in two parts and puts them in the context of the theory of international relations. The first part concentrates on global trends, while 


\begin{abstract}
the second part, besides global trends, discusses global risks in connection with these trends. As we can observe based on these sources, forecasts in the second decade indicated the continuation of trends described in the previous decade with the addition of further considerations based on new developments. Trends identified in the second decade included economy, technology, climate change, demography, society, governance and conflicts in the light of recent events. The second part of the paper in addition to global trends discusses global risks and their potential impacts which are related to the global trends. During the years following the October 2008 global financial crisis, the uncertainties of economic recovery dominated the risks. From the middle of the decade, the attention of the expert community gradually turned towards climate change and its consequences. By the end of the decade both the likelihood and the impact of climate change became the dominant risk. Risks related to the attacks against information infrastructures came second after climate change at the 2019 Davos Forum. Among the gradually evolving medium and long-term risks, it is justified to highlight the ever-growing income and assets inequalities which - according to many experts - constitute the principle cause of social polarisation and political conflicts.
\end{abstract}

Keywords: resilience, likelihood of risks, risks interconnections, post-truth era, trilemma

\title{
Megatrendek a második évtizedben
}

\section{Elörejelzések 2030-ig}

Az egyének cselekvőképességének megerősödése: Az információs technológiák globális folyamatokra gyakorolt hatása már korábban részévé vált a tudás új forrásait és eszközeit vizsgáló elemzéseknek. Az új felismerés szerint az adatok és információk egyre növekvő tömegének elérhetősége a tudás elmélyítése mellett hozzájárult az egyének cselekvőképességének megerősödéséhez is. Az egyes emberek vagy kisebb csoportok alkalmassá váltak jelentős hatások kiváltására a politika, a gazdaság és a társadalmi folyamatok területén. A megnövekedett egyéni cselekvőképesség okai között a National Intelligence Council prognózisa első helyen a szegénység csökkenését és a globális középosztály abszolút számának és arányainak lényeges növekedését jelölte meg. Ez a változás Kelet-Ázsiában, mindenekelőtt Kínában és Indiában történik már napjainkban is a leglátványosabban. Ezzel szemben a gazdaságilag fejlettebb nyugati államokban a középosztály helyzetének alakulása nem ilyen egyértelműen pozitív, mivel relatívan kisebb arányban részesült a globalizáció eredményeiből. A világszerte növekvő középosztály jövedelmi viszonyai átalakítják a fogyasztás szerkezetét, és hatást gyakorolnak a kormányok gazdaságpolitikájára. A prognózisok elkerülhetetlennek tartják az új társadalmi erők fokozódó nyomását a társadalmi-politikai változások kikényszerítésére. A globális középosztály növekedése mellett azonban továbbra is számolni kell a mélyszegénység és a gazdagság közötti tovább növekedő szakadék problémájával. Ez a szakadék országokon belül politikai és társadalmi konfliktusokhoz vezethet.

Az egyének gazdasági státuszának emelkedése egyrészt függ az oktatás színvonalától, másrészt új igényeket támaszt az oktatási rendszerekkel szemben. Becslések szerint a formális oktatásban eltöltött idő általános növekedése várható világszerte. Ennek része a nők 
nagyobb arányú részvétele mind az oktatásban, mind a munkaerőpiacon. Míg az oktatás területén az elmúlt évtizedekben csökkent a társadalmi nemek közötti egyenlötlenség, addig a gazdaságban és a politikában ennek a hatása kevésbé érzékelhető. A nők aktívabb részvétele a munkaerőpiacon enyhítheti az átlagéletkor növekedése következtében fellépő munkaerőhiányt. Számos ország, mindenekelőtt a skandináv államok példája pedig azt bizonyítja, hogy a nők nagyobb számú részvétele a politikában hozzájárul a jó kormányzáshoz. Néhány tanulmány szerzője arra a következtetésre jutott, hogy ahol több nő foglal el vezető pozíciókat a törvényhozásban és a kormányban, ott kisebb a korrupció.

A Nyugat eredeti feltételezése, hogy a globalizációval világszerte elfogadottá válnak olyan alapértékek, mint a tudományos érvelés, az individualizmus, a szekuláris kormányzás és a jog uralma, nem feltétlenül következik be, mivel a fejlődő világ ragaszkodik a hagyományos társadalmi, politikai, vallási és kulturális normáihoz. A világ ideológiai szférájában erősödnek a konfliktusok és az államok társadalmai belülről is megosztottabbá válnak vallási, etnikai, kulturális és világnézeti vonalak mentén. A politikai iszlám egyes országokban és a nemzetközi színtéren játszott szerepét úgy is tekinthetjük, mint a globális trendek által kiváltott reakciók egy lehetséges változatát. A demokratikus rendszerek és a politikai szabadságjogok terjedése lehetővé tette más vallások aktivizálódását is, amelyek gyakran fontos pozitív szociális funkciókat töltenek be, amelyeket a kormányok vagy elhanyagolnak, vagy nem képesek ellátni.

Az egyének és csoportok, kihasználva a megerősödött cselekvési képességeket, aktivizálódnak az egyre differenciáltabbá váló globális ideológiai térben. Amennyiben ez a trend találkozik a természeti erőforrások szűkülésével és a forrásokért folytatott geopolitikai versengéssel, az államoknak növekvő nemzetközi feszültséggel és konfliktusokkal kell szembenézni. ${ }^{1}$

A hatalom fokozódó diffúziója: A hatalmi viszonyok változása az államok között, és az átrendeződés iránya az államoktól az informális hálózatok felé drámai változásokat idéz elő a 2030-ig terjedő időszakban. A GDP, a népesség nagysága, a katonai kiadások és a technológiai befektetések tekintetében Ázsia megelőzi az Egyesült Államokat és Európát együttvéve. Várhatóan Kína válik a legnagyobb gazdasági hatalommá, megelőzve az Egyesült Államokat. Előrejelzések szerint azonban 2030-ra bekövetkezik a munkaképes korú lakosság számának csökkenése és ez Kína gazdasági növekedésének lassulásához vezet. Ugyanezen időszakban India demográfiai struktúrája hozzájárul a gazdasági növekedés fokozásához. A két ázsiai nagyhatalom demográfiai folyamatai közötti különbség, amely India számára előnyös, csökkenti a közöttük ma még meglévő különbségeket a gazdasági potenciál területén. Ami az összesített hatalmi mutatók által jelzett eltolódás másik oldalát illeti, folytatódik Európa, Japán és Oroszország lassú, viszonylagos gazdasági hanyatlása. A hatalmi viszonyok átalakulását, főleg annak dinamikáját bemutató elemzések szerint, a történelem során nem volt példa a nemzetközi hatalmi struktúra ilyen gyors átalakulására, beleértve a 19. és a 20. században történt hatalmi eltolódásokat is.

Global Trends 2030: Alternative Worlds, [online], 2012. 12., National Intelligence Council, 9-15. o. Forrás: Globaltrends2030.files.wordpress.com [2018. 10.31.] 
Az anyagi forrásokra épülő nemzeti hatalom eltolódása a nemzetközi kapcsolatokban új hatalmi központok irányában kiegészül egy hasonlóan lényeges hatalmi változással. Az új kommunikációs technológiák lehetővé teszik olyan nemzetközi hálózatok kialakulását, amelyekben államok és nem állami szereplök egyaránt részt vehetnek. Ezek a sokszínü, változatos célokkal fellépö hálózatok képesek lesznek akadályokat gördíteni a kormányok politikái elé. Az új szereplök képesek lesznek arra is, hogy megakadályozzák hegemonikus hatalom kialakulását a nemzetközi rendszerben. Ebben az alakuló közegben a kormányok számára fontos teendő lesz, hogy partnereket találjanak céljaik eléréséhez. Részvétel nemzetközi intézményekben, csatlakozás nemzetközi szerződésekhez lehet az egyik fontos útja az új nemzetközi realitásokhoz való alkalmazkodásnak. A nem állami szereplők és az állampolgárok érdekei közösek abban, hogy a kormányokat elszámoltathatóvá és tevékenységüket átláthatóbbá tegyék. A nagy mennyiségű adattal és információval rendelkező vezető információs technológiát képviselő társaságok hatalma a manipulációs képességükre épül. Információs monopolhelyzetük lehetőséget biztosít számukra a társadalmi valóság és az emberi magatartást befolyásoló tényezők pontos ismeretére. Ezen a területen az állami szereplők versenytársaivá válhatnak. ${ }^{2}$

Demográfiai folyamatok: Becslések szerint 2030-ra a Föld lakossága eléri a 8,3 milliárd föt. $\mathrm{Az}$ államok lakosságának életkor szerinti struktúrája változatos marad, de jellemző lesz az átlagéletkor növekedése, amely a szubszaharai Afrika kivételével csaknem valamennyi államban tapasztalható lesz. Míg a legfiatalabb társadalmakban a medián életkor 25 év, addig Németországban és Japánban már meghaladta a 45 évet. Az OECD-hez tartozó államok csoportja megközelíti ezt a mutatót. A nyugdíjas korú lakosság arányának növekedése miatt az érintett országokban fokozódó nyomás nehezedik a kormányokra a nyugdíj- és egészségügyi rendszer finanszírozásának biztosítása érdekében. A fenti demográfiai trendekhez való alkalmazkodás olyan eszközei, mint az adók emelése, a nyugdíjkorhatár emelése vagy a munkaidő meghosszabbítása társadalmi feszültségekhez vezethet. Megoldásként kínálkozik a kiadások átcsoportosítása más területekről, mint például a védelmi kiadások csökkentése, amely nyilvánvaló megoldásként kínálkozott már a korábbi időszakokban is.

A 20. század utolsó három évtizedének tapasztalatai szerint a fegyveres etnikai konfliktusok 80\%-a jellemzően olyan országokban robbant ki, ahol a lakosság átlagéletkora alacsony volt. Amennyiben ez a trend folytatódik, akkor a magas születési arányszám a potenciális konfliktusok egyik fontos előrejelzése marad. Jelenleg a magas születési arányszám, a lakosság alacsony átlagéletkora és az etnikai-törzsi-vallási ellentétek magas szintje a szubszaharai afrikai államokban, a Közel-Keleten, Dél-Ázsiában (Afganisztánban és Pakisztánban), valamint Közép- és Dél-Amerika egyes régióiban támasztja alá az erőszakos konfliktusok valószínüségét.

A globalizáció első szakasza a 19. század végén és a 20. század elején nagy migrációs hullámot indított el részben Európán belül, részben Európából az amerikai kontinensre. Az első ipari forradalom fontos tényezője volt ennek a nemzetközi migrációs hullámnak. A nemzetközi migrációra ösztönző okok között ma szerepet játszanak a gazdag és szegény

2 Uo., 16-20. 
államok közötti aránytalanságok a lakosság korösszetételében, egyenlőtlenségek egyes államok és régiók között a jövedelmek tekintetében, és a migrációs hálózatok kialakulása a kibocsátó és befogadó államok között. Ezek a tényezők szorosan összefüggenek a globalizáció megatrendjeivel. A nemzetközi migráció mellett nagyarányú migráció várható az államokon belül is. A belső migráció mozgatórugói között szerepel az urbanizáció, a természeti környezet változásai, a szélsőséges időjárási események és a természeti katasztrófák. Afrika és Ázsia mezőgazdasági területeiről százmilliók vándoroltak el a klímaváltozással összefüggő olyan okok miatt, mint az aszály és az árvizek. Becslések szerint Kínában 250 millió ember vált belső migránssá, és költözött a városokba a jobb megélhetés reményében.

Becslések szerint 2030-ra a Föld népességének 60\%-a városlakó lesz. A városok ott növekednek a leggyorsabban, ahol magas lesz a születési arányszám. Ebből következően az új megavárosok a jelenlegi fejlődő világban alakulnak ki. A gyorsuló urbanizáció, ha a kormányok jól menedzselik, hozzájárulhat Ázsia és Afrika államainak gazdasági versenyképességéhez. Azonban, ha a várostervezés nem fordít figyelmet a szolgáltatások arányos fejlesztésére, az urbanizáció folyamata negatív következményekkel járhat. A városok növekedése és gazdasági szerepük erősödése előrevetíti az önkormányzatok hatáskörének bővülését, a kormányzás decentralizációját. ${ }^{3}$

Az élelmiszer-, víz- és energiaellátás erősödő kapcsolata: A Föld népességének növekedése, az urbanizáció felgyorsulása és a középosztály világméretü kiszélesedése fokozódó igényeket támaszt a természeti erőforrásokkal szemben. Az ázsiai államok kormányainak külpolitikájában érzékelhetők a törekvések, hogy hosszú távú politikai és gazdasági megállapodásokkal biztosítsák a hozzáférést a döntően a fejlődő országok területén lévő energiaforrásokhoz. A kínai állami tulajdonban lévő vállalatok aktivitása kiemelkedő ezen a téren.

A már említett demográfiai okok következtében az élelmiszer-fogyasztás 35\%-kal nő a 2030-ig terjedő időszakban. Ugyanezen periódusban a vízfogyasztás 40\%-kal lesz magasabb, amelyben szerepet játszik a mezőgazdaság növekvő vízigénye és az urbanizáció felgyorsulása. A Föld lakosságának 40\%-a olyan területeken él, ahol több ország osztozik a vízlelőhelyeken. A vízfogyasztás jelenlegi trendjei alapján készített prognózisok szerint a jelzett periódus végére a világ népességének fele súlyos vízhiánnyal szembesül. A klímaváltozás jelentős hatással lesz mind az élelmiszer-termelésre, mind a vízhozamokra. A klímaváltozás hatásairól készített elemzések szélsőséges változásokat prognosztizálnak, a csapadékos területek még csapadékosabbá, a szárazság által sújtott területek még szárazabbá válnak.

A fejlődő országokban a jövedelmek növekedése következtében növekedett a húsfogyasztás. A hús iránti kereslet növekedése az állattenyésztésre gyakorolt hatáson keresztül ösztönzően hatott a mezőgazdasági termelésre, és növelte a vízfogyasztást. Globális méretekben a vízfogyasztás $70 \%$-a a mezőgazdaságra esik, ezen belül is nagy súllyal szerepel az állattenyésztés. A földművelésre hasznosítható területek mérete korlátozott, a felhasználható vízkészletek nagysága véges, és mindkettő hatékony felhasználása egyre szorosabb kapcsolatban van a klímaváltozással. A Föld lakosságának élelmezése, a növekvő igények

Uo., 21-30. 
kielégítése a globális biztonság fenntartásának egyik fontos feltétele, ezért az élelmiszertermelés és a vízkészletek felhasználása a klímaváltozás hatásainak figyelembevételével a nemzetközi együttműködés kiemelkedően fontos témájává válik.

2030-ig a globális energiafelhasználás 50\%-os növekedésével számolnak a prognózisok. A növekvő igényeket kisebb részben az OPEC-tagállamok termelésének fokozásával, nagyobb részben az Egyesült Államok palaolaj- és palagáztermelésének növelésével elégítik ki. Ezek a nem hagyományos energiaforrások számos országban megtalálhatók, azonban környezetvédelmi meggondolások akadályozzák a kitermelést, vagy a technológiai feltételek nem állnak rendelkezésre. Az előrejelzések nem számolnak az olyan alternatív energiaforrások felhasználásának jelentős növekedésével, mint a szél-, a nap- és a vízenergia. ${ }^{4}$

\section{A megatrendeket módosító lehetséges tényezők}

A négy megatrend önmagában lényegesen átalakítja a nemzetközi rendszert az elkövetkező évtizedben. Célszerü azonban további tényezők vizsgálata, amelyek interakciója egymással és a megatrendekkel módosíthatja azok tényleges hatásait. Szakértői vélemények szerint az alábbi tényezők figyelembevétele fontos lehet a megatrendek hatásainak mérlegelése során.

A válságra érzékeny globális gazdaság: A nemzetközi gazdaság egyik fő jellemzője marad, hogy az egyes országok és régiók gazdasági növekedésének üteme fokozottan eltérő lesz, és ezzel tovább növekszik a globális egyensúlytalanság és a rendszer kiszámíthatatlansága. Kulcskérdés marad, hogy az eltérő gazdasági növekedési ütem tovább növeli a globális rendszer sebezhetőségét és végül összeomláshoz vezet, vagy a többpólusú növekedési központok kialakulása fokozza a globális gazdasági rendszer válságokkal szembeni ellenálló képességét. A gazdaságilag fejlett országok és a feltörekvő piacgazdaságoknak az új helyzethez történő alkalmazkodásra irányuló közös erőfeszítésein múlik, hogy a politikai és gazdasági válságok elkerülhetők lesznek-e a jövőben. Számos európai országnak és Japánnak megoldást kell találni a gazdasági növekedés fenntarthatóságát akadályozó problémákra, amelyek között kiemelkedő helyet foglal el a népesség gyorsuló elöregedése. Kína és India esetében kulcskérdésként tartják számon a gazdasági hatékonyság növelését, ami szükségessé teszi a politikai és társadalmi intézmények mélyreható átalakítását. A globális gazdaság többpólusú jellegének erösödése, a Nyugat csökkenő befolyásolási képessége mellett, fokozhatja a nemzetközi rendszer kormányzásának nehézségeit, amennyiben a felemelkedő hatalmak, mint Kína és India, érdeklődése csökken a nemzetközi együttműködés iránt és elsősorban belső ügyeikre koncentrálnak.

A gazdasági visszaesések és pénzügyi válságok történetének tanulságai szerint a globális adósságállomány túlzott felhalmozódása a válság előjelének tekinthető. Számos szakértői vélemény figyelmeztet a kormányok felelősségére az eladósodás megfelelő keretek között tartása érdekében. Az eladósodás következményeinek bizonytalanságát fokozza a kamatlábak alakulásának kiszámíthatatlansága. Amennyiben a következő évtizedben recesszió

$4 \quad$ Uo., 31-38. 
és pénzügyi válság következik be, a globális munkaerőpiaci helyzet, mindenekelőtt a népesség korösszetételében meglévő nagy és egyre növekvő aránytalanságok megnehezítik annak kezelését. ${ }^{5}$

A kormányzással szembeni kihívások: A jövő fontos kérdése, hogy a nemzeti kormányok és a nemzetközi intézmények képesek lesznek-e kihasználni a változásokban rejlő lehetöségeket, vagy képtelenek lesznek az alkalmazkodásra. A nemzetközi rendszer instabilitásának két forrásával lehet számolni a jövőben. Elöször, azok az országok, amelyek az autokratikus rendszerből a demokratikus rendszerré történő átalakulás folyamatának közbülső szakaszában vannak, általános tapasztalatok szerint jelentős instabilitással néznek szembe. Másodszor, kevésbé stabilok azok az országok, amelyekben a kormányzati rendszer nincs összhangban a társadalom más területeinek, mindenekelőtt a gazdaságnak a fejlettségével. A fenti két kockázati faktor jelen van és hatást gyakorol a világ sok országának belpolitikájában, amelyek jellemzően Afrikában, Ázsiában, a Közel-Keleten és Közép-Amerikában találhatók. Ösztönzően hatnak a demokratikus átalakulás folyamatára a növekvő jövedelmek, a magasabb iskolai végzettség és a magasabb átlagéletkorral jellemezhető életkorstruktúra. Ugyanakkor a demokratikus politikai rendszer kialakulásának folyamata gyakran destabilizáló hatást gyakorol a társadalomra.

Az információs technológia új eredményei az állampolgárok ellenőrzésének hatékony eszközeit biztosítják a kormányok számára, amelynek a pozitív és negatív következményei egyaránt előtérbe kerülhetnek. A legfontosabb pozitív hatás a bünözés és mindenféle illegális tevékenység felderítése és felszámolása. A kormányok fontos partnerei lehetnek ebben a tekintetben az internetszolgáltatók, amelyek ellenőrzik az elektronikus kommunikációt. A szakértői vélemények azonban lényegesen eltérnek az információs technológia jövőbeni társadalmi és politikai hatásainak megítélésében. A politikatudomány képviselői óvatosabbak, míg az információs technológia képviselöi optimistábbak az állam hatalomgyakorlásának módjára történő hatás megítélésében. Az információ eszközeivel megerősített kormányok azonban - különösen a nem demokratikus rendszerek esetében - visszaélhetnek ezekkel az eszközökkel, amennyiben azok alkalmazása az állampolgárok jogainak sérelmét okozza.

A modern kommunikációs eszközökkel megerősített állampolgárok nyomást gyakorolhatnak a kormányokra a nagyobb nyitottság és átláthatóság érdekében. Nagyobb beleszólást követelhetnek a politikai döntéshozatalba. A modern kormányzás számos új problémával találja szemben magát, amelynek a megoldásában az állampolgárok aktívabban kívánnak részt venni, mint korábban. Ilyen probléma a világméretü és egyre növekvő vagyoni egyenlőtlenség és a mélyszegénység, amellyel szembeállítható az extrém gazdagodás, a megtermelt jövedelmeknek a társadalom többségének morális érzékét sértő elosztása. Az egyenlőség, a nyitottság és az igazságosság eszméje egyre nagyobb hangsúlyt kap mind az egyes országokban, mind a nemzetközi rendszerben. A jövő nagy kérdése, hogy a politikai és gazdasági elitek érdekeit képviselő kormányok és a társadalom többségét képviselő állampolgári kezdeményezések közötti vitákban és érdekkonfliktusokban melyik

Uo., 43-50. 
oldal tudja hatékonyabban alkalmazni az információs technológia biztosította lehetőségeket. A National Intelligence Council 2012-ben kiadott tanulmánya erre a kérdésre az alábbi választ adta: „A hatékony eszközök birtoklása ellenére azok a kormányok, amelyek elmulasztják a liberalizációt és nem válnak nyitottá, vesztes csatával számolhatnak." ${ }^{6}$

Az egyenlőség és az igazságosság, mint egyre nagyobb érdeklődést kiváltó témák nemcsak az országokon belül, hanem a nemzetközi rendszerben is hatást gyakorolnak. A felemelkedő hatalmak sürgetik a nemzetközi rendszer demokratikusabbá tételét, mivel szerintük a második világháború utáni rend egyoldalúan a nyugati hatalmaknak biztosított előnyöket. A hatalom eltolódása és növekvő diffúziója párosulva a lehetséges következményekről szóló vitákkal, a nemzetközi politika terepét és a kormányzás módszereit jelentősen átalakítja. Tovább erősödik a regionális együttmüködés és a kormányzás decentralizációja, amelyben nagyobb szerepet kapnak a városok és a közöttük kialakult kapcsolatok. Ez a folyamat átalakítja a multilaterális intézmények és a központi kormányok szerepét. ${ }^{7}$

Potenciális konfliktusforrások: Az elemzések összefüggést találtak számos fejlődő ország esetében a népesség átlagéletkorának növekedése és a fegyveres belső konfliktusok számának csökkenése között az elmúlt két évtizedben. A prognózisok szerint ez a trend folytatódik a jövőben is. Két tényező azonban befolyásolhatja alakulását. Az egyik az etnikai közösségek viszonyának alakulása a soknemzetiségü államokban. A másik a nemzetközi közösség hajlandósága az egyre költségesebbé váló békefenntartó müveletek folytatására.

Az államok közötti konfliktus valószínüségének megítélésében fontos körülmény, hogy jelenleg az államok elsődleges érdeke a gazdasági fejlődés, és tudatában vannak annak, hogy kölcsönösen függenek egymástól gazdasági céljaik elérésében. Azonban ez a helyzet megváltozhat, ha lelassul a gazdasági növekedés, fokozódnak az ellentétek a nagyhatalmak között, és mindezek betetőzéseként drámai romlás következik be a természeti környezet állapotában. Az események ilyen alakulása fokozhatja a nemzetközi konfliktusok kockázatát. Az államok közötti konfliktus valószínüségét növelheti az egyének és kis csoportok megnövekedett cselekvőképessége, különösen akkor, ha ez párosul a tömegpusztító fegyverekhez és az információs hadviselési eszközökhöz való hozzájutással. A kialakuló helyzethez való alkalmazkodás egyik formája lehet, hogy egyes államok fegyveres erői válaszként felkészülnek az irreguláris hadviselés taktikájának alkalmazására.

Növelhetik a konfliktusok valószínüségét a nemzetközi rendszert leginkább befolyásolni képes nagyhatalmak stratégiájában és taktikájában váratlanul bekövetkezett kedvezőtlen fordulatok. Ilyen változásokat okozhat a korlátozottan rendelkezésre álló erőforrásokért folytatott geopolitikai versengés. A technológia oldaláról a nagypontosságú csapásmérő eszközök, az információs hadviselés és a biológiai fegyverek mint a terrortámadás eszközei okozzák a legnagyobb bizonytalanságot. ${ }^{8}$

A megatrendekkel kapcsolatos viták napirendjén szerepelt az a kérdés, hogy vajon a felemelkedő új nagyhatalmak szándékoznak-e a nemzetközi rendet alapvetően átalakítani. A többségi vélemények szerint az új nagyhatalmak részéről nem tapasztalhatók a 20. századi

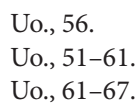


agresszív nagyhatalmi politikákhoz hasonlítható törekvések. Az Egyesült Államok és Kína viszonyát a nemzetközi rendre legnagyobb hatást gyakorló tényezőként értékelték. A két nagyhatalom a versengés ellenére az eddigiek során bizonyította, hogy kész az együttműködésre a közös veszélyek elhárítása és a közös érdekek védelme céljából. ${ }^{9}$

\section{Elörejelzések 2035-ig}

A 21. század második évtizedének végén készült elemzések az „ellentmondásos” (paradox) jelzőt alkalmazták a globális nemzetközi rendszer folyamatainak leírásához. A korábbi évtizedek technológiai vívmányai és gazdasági eredményei számos pozitív változást hoztak az egész emberiség életében. Ugyanakkor az elemzések eredményeként megjelenő finomítások az öt évvel korábban megfogalmazott megatrendeken azt jelzik, hogy a belátható jövő nagyobb fenyegetéseket és ugyanakkor gazdagabb lehetöségeket kínál, mint a történelmi múlt bármely megelőző korszaka.

A 2030-ig terjedő időszakra prognosztizált megatrendek továbbra is iránymutatók maradtak, azonban kiegészültek néhány további finomítással. A megatrendek pontosítását arra a feltételezésre alapozták, hogy lassulni fog a globális gazdaság növekedése, a hatalmi képességek diffúziója következtében egyre több szereplö csatlakozik a geopolitikai rivalizáláshoz, az államok közötti értékekről és érdekekről szóló viták intenzívebbé válnak, és csökken a szabályokra épülö nemzetközi rend iránti elkötelezettség, amely a második világháború vége óta müködött.

Egyes kormányok kísértést érezhetnek, hogy rendet teremtsenek egy olyan időszakban, amikor mind a belpolitikában, mind a nemzetközi színtéren élénk viták zajlanak a kormányzásról és a kormányok szerepéről. Az anyagi eszközökre és forrásokra építő rendteremtési kísérletek sikerének valószínüsége elmarad a kapcsolatokra, hálózatokra és információs képességekre építő politikák sikerének valószínűsége mögött. A globalizáció fokozódó ellentmondásos jellege indokolttá teszi a demokratikus társadalom jövőjéről folytatott vitákat. Minden országon belül aktuális kérdéssé válik, hogy hogyan lehet a globalizáció előnyeit elérhetővé tenni a társadalom számára, miközben a káros hatások elkerülhetővé vagy csökkenthetővé válnak. A 2035-ig terjedő időszakra vonatkozó prognózisok az alábbi folyamatokat emelik ki:

Globális demográfia: A gazdag országok népességének átlagéletkora tovább emelkedik, a szegény országoké ezzel szemben nem. A demográfiai elörejelzések szerint a Föld népessége a jelenlegi 7,3 milliárdról 8,8 milliárdra nő. 2035-ig Japán népességének medián életkora 52,4 év, Németországé 49,6 év lesz. Ezen időszak alatt a medián életkor Kínában 45,7 évre emelkedik. Ezzel szemben a legfiatalabb korösszetételü országokban a medián életkor 25 év. A munkaképes korú népesség csökkenését jelzik az ENSZ adatai, amelyek szerint 1995 és 2015 között a munkaképes kort elérők száma 1,2 milliárd volt, a 2015 és 2035 közötti időszakban ez a szám várhatóan 850 millió lesz. A munkaerőpiacra újonnan belépők döntő többsége Afrikában és Dél-Ázsiában várható, ahol a népesség növekedésétől messze

9 Uo., 105. 
elmarad az új munkahelyek teremtése, valamint az infrastruktúra, az oktatás és egészségügy fejlesztése. A demográfiai, gazdasági és természeti környezeti okok miatt az országokon belüli és a határokon átnyúló migráció továbbra is az egyik legfontosabb globális probléma marad. Jelenleg a világon minden 112 . személy vagy országon belüli, vagy más országban megélhetést vagy oltalmat kereső migráns. A migránsok helyzetének további romlását idézheti elő az etnikai, vallási és ideológiai okok miatt kirobbant erőszakos konfliktusok terjedése. ${ }^{10}$

Globális gazdaság: A világgazdaság átrendeződése folytatódik a közeli és távoli jövőben egyaránt. A fejlett gazdaságok számára fontos feladat lesz a gazdasági növekedés lassulásának megállítása és az eddigi életforma megőrzése a gazdasági hatékonyság és a munkaképes korú lakosság csökkenése ellenére. A fejlődő világ országaiban fontos feladat marad a mélyszegénység felszámolása és a munkaerőpiacra belépő fiatalok számára munkalehetőségek teremtése. Valamennyi ország számára egyre sürgetőbb feladat lesz új munkahelyek teremtése a robotizálás és automatizálás által a termelő szférából kiszorított munkaerő számára. Napirendre kerül az új foglalkozások, új szolgáltatások és új gazdasági szektorok bevezetése, amelyekhez az oktatási és képzési rendszerek biztosítják a felkészült munkaerőt.

A globalizációhoz füződő viszony, annak kedvező vagy kedvezőtlen megítélése elkerülhetetlenül napirendre került a 21. század második évtizedében. A nyertesek és vesztesek számbavétele fontos jelzésekkel szolgált az általános kép kialakításához, ami - mint azt a forrásként használt tanulmány címe is jelzi - igencsak ellentmondásos. A globalizáció legintenzívebb szakaszában, az 1988 és 2008 közötti időszakban vizsgálták a háztartások bevételeinek alakulását a világ népességének különböző kategóriáiban. A családi jövedelmek alakulása alapján sorolták a nyertesek vagy a vesztesek csoportjába a népesség különböző kategóriáit. A felmérés eredményei szerint a legnagyobb nyertesek a világ leggazdagabb vállalkozói, amely csoportnak a felét az Egyesült Államok népességének leggazdagabb 12\%-a teszi ki. A Japán, Németország, Nagy-Britannia és Franciaország népességének 3-6\%-át képviselő extrém gazdagok, valamint Brazília, Dél-Afrika és Oroszország népességének leggazdagabb 1\%-a szintén a nyertesek csoportjába sorolható. A globális jövedelmek elosztásának vizsgálata azt is kimutatta, hogy a felemelkedő gazdaságokban - döntően Kínában és Indiában - a középosztály szintén a nyertesek csoportjába tartozik.

A globalizáció legnagyobb vesztese a szubszaharai Afrika országainak népessége, amelynek a globalizáció vizsgált időszakában nem sikerült kiemelkedni a mélyszegénységből. A háztartások bevételeinek tanulmányozása azt is kimutatta, hogy a gazdag államok állampolgárai többségének a vizsgált két évtizedben stagnált a jövedelme. Végül a vizsgálat arra is fényt derített, hogy a volt kommunista országok népességének döntő többsége szintén a globalizáció veszteseihez sorolható. ${ }^{11}$

Technológia: Az automatizáció, a mesterséges intelligencia és más fejlett technológiák hozzájárulnak a termelékenység növeléséhez, ha az oktatás színvonala, az infrastruktúra

10 Global Trends: Paradox of Progress, [online], 2017. 01., National Intelligence Council, 8-10. o. Forrás: Globaltrends2030.files.wordpress.com [2018. 10.31.]

11 Uo., 11-13. 
fejlettsége, az állami szabályozás és a vállalati menedzsment gyakorlata lépést tud tartani a technikai fejlődéssel. Amilyen mértékben szorítja ki az új technológia az élőmunkát a termelésből és szolgáltatásokból, olyan mértékben gyakorol nyomást a munkabérekre. Ennek következtében csökkennek a személyes jövedelmekre kivetett adóbevételek, amelyek fontos részét képezik az államok költségvetésének. Elkerülhetetlenné válik az adórendszerek mélyreható reformja.

A technológiai fejlődésnek az adórendszerekre gyakorolt lehetséges hatása jól szemlélteti, hogy a jelenlegi trendek között az új technológiának lehetnek a legváratlanabb kedvező, de adott esetben kedvezőtlen és destabilizáló hatásai a társadalmakra. Ma még nehéz lenne prognosztizálni a kommunikáció, a mesterséges intelligencia, a robotok, a biotechnológia és a nem hagyományos energiaforrások terén elért tudományos eredmények gyakorlati alkalmazásában rejlő lehetőségeket.

Az előző történelmi korszakok tanulságai alapján megalapozottan feltételezhető, hogy a jelenlegi technikai forradalom pozitívan járul hozzá a gazdasági fejlődéshez. Nagyobbnak tünik a bizonytalanság a társadalmakra gyakorolt hatás, és az egyes emberek sorsának alakulása tekintetében. Nincs még megnyugtató válasz arra a kérdésre, hogyan érinti az információs technológia forradalma az egyének magánszféráját és emberi méltósághoz kapcsolódó jogait. A génmódosítás gyakorlati alkalmazása egzisztenciális kockázatokat vet fel és alapvető etikai normákat érint. Egyre sürgetőbb a nemzeti és még inkább a nemzetközi szabályozás az új technológiák által leginkább érintett érzékeny területeken. A nemzetközi szabályozást nehezíti, hogy a technológia hatásaival foglalkozó viták inkább távolítják, mint közelítik a különböző országok által preferált értékeket és érdekeket. ${ }^{12}$

Az identitások hangsúlyosabbá válnak: A technológia és a kultúra kölcsönhatásának erősödésével egyenes arányban erősödnek az egymást kölcsönösen kizáró vallási és etnikai identitások, mivel az emberek keresik az orientációs pontokat a gyorsan változó és bizonytalan gazdasági, társadalmi és technológiai környezetben. A hatalmi technikák részévé válik a társadalmak lázas önazonosság keresése, mert megkönnyíti a politikai mobilizációt és ellenőrzést. Az identitáspolitika erősödése nyomán csökken a tolerancia és a másság elfogadása.

Paradox módon az egyre szorosabban összekapcsolt világ országai között nem a különbözőségek csökkenése, hanem ellenkezőleg a különbözőségek növekedése következett be. ${ }^{13}$ A populista jelzővel illetett politikai pártok és mozgalmak a globalizáció vesztesei közé tartozó gyarapodó számú ember véleményének adnak hangot, amikor bírálják a politikai és gazdasági eliteket, amelyek önös érdekeik követése közben nem foglalkoznak a védelemre szoruló társadalmi csoportokkal. Az identitáspolitikák alapjaira épülő nemzeti politikai dinamikák fokozatosan szükítik az alternatív politikai megoldások lehetőségét. Az erőteljes vallási identitásra alapozott külpolitikák - a legjellemzőbb példák a Közel-Keleten

12 Uo., 14-16.

13 Ez a fejlemény ellentmond a nemzetközi kapcsolatokra vonatkozó számos elméleti tételnek, közöttük az integrációs elméleteknek. Az elmúlt két évtized globális trendjei bizonyosan hozzájárultak a felfokozott identitáskereséshez és a különbségek csökkenése helyett a különbségek növekedéséhez. Egy trendről bizonyosan állítható, hogy döntő szerepet játszott a különbözőségek percepciójának drámai megerősödésében. Ez a trend az egyre fokozódó vagyoni polarizáció mind az államokon belül, mind az államok között. (A szerző megjegyzése.) 
találhatók -, amelyek hajlamosak a nemzetközi környezetet ellenségesnek tekinteni, saját esélyeiket gyengítik a gyors változásokhoz való alkalmazkodásra. ${ }^{14}$

A kormányzás fokozódó nehézségei: A következő évtizedekben a lakosság biztonsággal és jóléttel kapcsolatos igényeinek kielégítése nem lesz könnyű feladat a kormányok számára. A társadalmak politikai polarizációja, a financiális korlátok és a megoldandó problémák sokasodása növekvő próbatétel elé állítja a kormányzati bürokráciákat. Számolni kell az információs lehetőségek segítségével nagyobb cselekvőképességre szert tett civil mozgalmakkal, amelyek segíthetik, de akadályozhatják is a kormányzati politikákat. A közvélemény elvárásai és a kormányok teljesítménye közötti szakadék növeli a bizalmatlanságot és az elégedetlenséget. Az elitet érintő korrupciós botrányok tovább súlyosbítják a problémát.

A fejlődő országok egy részében megerősödött középosztályok igénye is megerősödött a jó és korrupciómentes kormányzás iránt, és igénylik az elért életszínvonal megvédését is. A gazdaságilag fejlett államokban a lassú növekedés, a stagnáló jövedelmek és a növekvő egyenlötlenség miatt növekszik a középosztály elégedetlensége. Mindez olyan időpontban jelentkezik, amikor nő a globális adósság, erősödik a globális gazdasági verseny és a nemzetközi piacok kiszámíthatósága csökken. Számos országban tapasztalható, hogy a kormányzás demokratikus formáit és módszereit kombinálják az autokratikus rendszerekre jellemző elemekkel. Hosszadalmas és kimerítő vitákat igényel annak eldöntése, hogy a politikai rendszerek ilyen irányú fejlődése lesz-e a megfelelő válasz az egyre komplexebbé váló globális kihívásokra, vagy ellenkezőleg, a globális instabilitás növekedése lesz a következmény.

A nemzeti intézményekbe - kiemelkedően a politikai pártokba - vetett bizalom csökkenése együtt jár a nemzetközi intézményekbe vetett bizalom csökkenésével. Ez gátolja az intézmények cselekvőképességét és a szükséges intézményi reformok végrehajtását. A közös problémák megoldására törekvő kormányok a hagyományos multilaterális diplomáciai gyakorlat mellett alkalmi koalíciók szervezésével is kísérleteznek, amelyeknek részesei lehetnek az érdekelt üzleti vállalkozások és civil társadalmi csoportok. ${ }^{15}$

Változik a konfliktus természete: A konfliktusok valószínűsége - beleértve az államközi konfliktusokat is - növekszik a következő években. A kialakuló geopolitikai helyzet, az új technológiák és az új stratégiák átalakítják a hadviselésről vallott korábbi felfogást. A növekvő számú katonai és nem katonai eszközök alkalmazása elmossa a határokat a háborús és a békés helyzetek között. A jövő konfliktusaiban részt vevő felek az ellenfél társadalmi kohéziójának gyengítését, kormányzati funkcióinak bénítását és kritikus infrastruktúrájának rombolását tekintik elsődleges célnak. Nem az ellenfél katonai erőinek legyőzése, hanem a lélektani és geopolitikai előnyszerzés válik döntő stratégiai célkitűzéssé. A háború és a béke közötti elmosódó választóvonal megnehezíti a szemben álló felek számára az elrettentés és az eszkaláció hagyományos eszközeinek és módszereinek kezelését. A konfliktusoknak ebben a „szürke zónájában” az olyan hagyományos nyomásgyakorlási eszközök, mint a gazdasági kényszerítés, politikai felforgatás és titkos müveletek mellett egyre hatékonyabbá válnak az információs hadviselés és a félrevezető propagandakampányok

14 Uo., 17-18.

15 Uo., 18-19. 
módszerei. Az államok közötti gazdasági, politikai és biztonsági versengés a béke és háború közötti „szürke zónában” tartósabbá válhat annak tudatában, hogy a totális háború elkerülhető. ${ }^{16}$

Fenyegető klímaváltozás: A klímaváltozással gyakoribbá válnak a szélsőséges időjárási események, amelyek erősödő nyomást gyakorolnak a gazdaságra, a társadalomra, a politikai rendszerekre, és fokozzák a biztonsággal szembeni kihívásokat. A szélsőséges időjárási események hangsúlyosabban jelentkeznek a városokban, tengerpartokon és a vízhiányos régiókban. A múltban történt üvegházhatást kiváltó gázkibocsátás már húsz évre előre meghatározta az átlaghőmérséklet emelkedését, függetlenül a kibocsátást korlátozó jövőbeni intézkedésektől. Az időjárási szélsőségek fokozódása miatt nem zárhatók ki a váratlan drámai fordulatok sem.

A természeti környezettel kapcsolatos megbetegedések fő okozójává a légszennyezettség válik a következő 15 évben. Az elhalálozások száma növekszik, ha a kormányok nem tesznek intézkedéseket a levegő tisztaságának megőrzése és helyreállítása érdekében. A jövőben a humán és állati egészségügy szorosabban összekapcsolódik. A változó környezeti feltételek és a globális összekapcsoltság hatással lesznek a fertőzések földrajzi terjedésére. A nemzeti és a nemzetközi egészségügyi rendszereknek alkalmassá kell válni a lehetséges járványok okozta kockázatok kezelésére. A demográfiai és kulturális tényezők, a népesség öregedése, az urbanizáció, az alultápláltság, az egészségügyi rendszerek elhanyagoltsága és a növekvő egyenlőtlenségek következményeként számítani lehet olyan nem fertőző betegségek nagyobb gyakoriságára, mint a szív- és érrendszeri betegségek, a cukorbetegség és a mentális betegségek. ${ }^{17}$

\section{Globális kockázatok}

A második évtizedben a davosi Világgazdasági Fórum éves jelentései részletesen foglalkoztak a globális trendekkel összefüggő globális kockázatokkal. A World Economic Forum értelmezése szerint „a globális kockázat egy bizonytalan esemény vagy körülmény, amely, ha bekövetkezik, lényeges negatív hatást gyakorolhat számos országra vagy vállalkozásra a következő tíz évben" ${ }^{18}$ Az évente elkészített jelentések természetesen nem mentesek a szubjektív elemektől, amelyekkel számolni kellett a kockázatok minősítése során, annak ellenére, hogy a felmérések során kormányzati, üzleti és tudományos szakértői véleményeket hallgattak meg.

A 2013-as Világgazdasági Fórumra készített jelentés új fogalomként vezette be az ellenálló képesség/túlélőképesség (resilience) fogalmát, amely az államok képességét jelenti a globális kockázatokhoz való alkalmazkodásra és az esetleges negatív hatások következményeiből történő kilábalásra. Egy másik nagy hangsúlyt kapott elem a rendszerben történő gondolkodás, amely arra hívja fel a figyelmet, hogy a kockázatok összefüggenek egymással és átszelik az országok határait. A velük szembeni ellenálló képesség erősítése

16 Uo., 20-21.

17 Uo., 21-25.

18 The Global Risks Report 2016, [online], 2016, World Economic Forum, 6. o. Forrás: Wef.ch [2018. 10. 31.] 
sokoldalú együttmüködést igényel. A kockázatok rangsorolását egyrészt a bekövetkezésük valószínüsége (likelihood), másrészt a hatásuk nagyságrendje (impact) szerint végezték el. A 2013. évi jelentés a legnagyobb valószínűséggel bekövetkező globális kockázatként a súlyos jövedelmi különbségeket jelölte meg. A korábbi években a jelzáloglufi kipukkadása szerepelt ebben a pozícióban. A legnagyobb negatív hatást kiváltó kockázatként a pénzügyi rendszer összeomlása szerepelt a jelentésben. A tíz legvalószínübben bekövetkező és a legnagyobb hatást kiváltó kockázatok között szerepelt még a kritikus pénzügyi egyensúlytalanság, az üvegházhatást kiváltó gázok növekvő kibocsátása, a vízhiány, a népesség elöregedésének kezelésének problémája, az élelmiszerhiány és a tömegpusztító fegyverek tovább terjedése. ${ }^{19}$

A 2014. évi Világgazdasági Fórumra készített jelentés a kockázatok valószínüsége és lehetséges hatása mellett új szempontként elemezte azt is, hogy a számításba vett kockázatok közül melyek váltották ki a legnagyobb aggodalmat a megkérdezett szakértők körében. A válaszok alapján a vezető gazdasági hatalmaknál bekövetkező pénzügyi válságok adtak alapot a legintenzívebb aggodalmakra. A súlyos jövedelmi egyenlötlenségek továbbra is vezető pozícióban maradtak a valószínüség skáláján, és a legnegatívabb hatás tekintetében a pénzügyi válság továbbra is listavezető maradt.

A 2014. évi jelentés első alkalommal vizsgálta a globális kockázatok közötti kölcsönös kapcsolatokat (interconnections) és két markánsan elkülöníthető tényezőcsoportot azonosított. Az egyik gazdasági-társadalmi természetü csoport, amelyet a pénzügyi válságok, munkanélküliség, jövedelmi egyenlőtlenségek, politikai és társadalmi instabilitás, a pénzügyi intézmények és mechanizmusok kudarca és a likviditási válságok alkotnak. A másik tényezőcsoport alkotóelemei a klímaváltozás, a szélsőséges időjárási események, a vízhiány, az élelmiszerhiány, a természeti katasztrófák, a biodiverzitás csökkenése és az ökoszisztéma összeomlása. A két tényezőcsoport között mintegy összekötő kapocsként helyezkedik el a globális kormányzás kudarca, amelynek a két csoporton túl hatása lehet még az államok közötti konfliktusok kiéleződésére és a korrupció terjedésére. A különböző szempontok szerinti felmérések alapján készített elemzések a gazdasági, a társadalmi és a környezeti kockázatok dominanciájára világítottak rá. ${ }^{20}$

A kockázatokkal szembeni ellenálló képesség növelésének lehetőségét a kormányok, az üzleti világ és a civil társadalom szorosabb együttmüködésében jelölte meg a jelentés. Kiemelte a hosszú távú gondolkodás fontosságát az olyan ügyekben, mint a bizalom visszanyerése a politikai intézményekben, amelyektől a fiatal generációk elfordultak. A globális kockázatok feltérképezése és a közöttük lévő kapcsolatok jobb megértése alapvető feltétele a kollektív cselekvésnek. Mivel a kockázatok nagy része az egész nemzetközi rendszert érinti, sürgetően szükség van a globális kormányzás új modelljeinek kidolgozására, mert a jelentés szerint a jelenlegi struktúrák elavultak. ${ }^{21}$

2015-ben a korábbi évekhez képest nagyobb hangsúlyt kapott az a vélemény, hogy a világ országai nincsenek megfelelően felkészülve az egyre komplexebb módon megjelenő kockázatok kezelésére. A komplexitás világosabb megértése céljából a jelentés a kockázatokat

19 The Global Risks 2013, [online], 2013, World Economic Forum, 8-15. o. Forrás: Weforum.org [2018. 10. 31.]

20 The Global Risks 2014, [online], 2014, World Economic Forum, 9-25. o. Forrás: Weforum.org [2018. 10. 31.]

21 Uo., 52. 
öt kategóriába sorolta: gazdasági, környezeti, geopolitikai, társadalmi és technológiai kockázatok körébe. A 2007-2014 közötti időszakhoz képest a legnagyobb változás abban a tekintetben történt, hogy a gazdasági jellegű kockázatok, amelyek domináltak az előző periódusban, háttérbe szorultak és átadták helyüket a geopolitikai kockázatoknak. Ehhez hozzájárult Oroszország és Ukrajna területi konfliktusa, az úgynevezett „Iszlám Állam” megjelenése és a törékeny államok számának szaporodása. A valószínüségi skálán az első helyet az államközi konfliktus foglalta el. A regionális következményekkel járó államközi konfliktus a hatás nagyságrendjének skáláján is az első öt kockázat között található. ${ }^{22}$

A korábbi évekhez képest 2015-ben nagyobb hangsúlyt kapott a társadalmak instabilitása, amelynek egyik fő forrása a társadalmi-gazdasági egyenlőtlenségek további növekedése. A jelentés szerint az államok közötti jövedelmi különbségek csökkentek. Egy 2011-ben végzett felmérés adatai szerint az OECD tagállamaiban a népesség leggazdagabb 10\%-ának jövedelme kilencszer nagyobb mértékben nőtt, mint a legszegényebb 10\%-é. A jövedelmi aránytalanságok növekedésének vannak még szélsőségesebb esetei is, például Mexikóban, ahol a leggazdagabb 10\% jövedelmének növekedése huszonötszöröse a legszegényebb $10 \%$-ának. ${ }^{23}$

A kockázatok kölcsönös kapcsolatainak rendszerében két csoport emelkedik ki. Az egyiket a társadalmi instabilitás, a munkanélküliség, a nemzeti kormányzás kudarca, az állam válsága vagy összeomlása, az államok közötti konfliktus és a kikényszerített migráció alkotja. A másik csoport alkotóelemei a klímaváltozáshoz való alkalmazkodás sikertelensége, a szélsőséges időjárási események, az ember okozta környezeti katasztrófák, a víz- és az élelmiszerhiány. A 2015-ös jelentés első alkalommal készített elörejelzést arról, hogy mely kockázatok növekedése várható a jövőben. Az alábbi kockázatok növekedését prognosztizálta: növekvő jövedelmi egyenlőtlenségek, a társadalmak erősödő polarizációja, elöregedö népesség, gyengülő nemzetközi kormányzás, erősödő összekapcsoltság az államok között, erősödő középosztály a feltörekvő gazdaságokban, klímaváltozás, a természeti környezet további pusztulása és az urbanizáció folytatása. ${ }^{24}$

2016-ban a Világgazdasági Fórumon nagy figyelmet kapott az a tény, hogy elörejelzések szerint abban az évben az évi átlaghőmérséklet $1^{\circ} \mathrm{C}$-kal meghaladja az ipari forradalom előtti átlaghőmérsékletet. Az erőszakos konfliktusok miatt 60 millió ember volt kénytelen elhagyni lakhelyét és vált belső vagy külső menekültté. Becslések szerint a számítógépes bűnözés által okozott kár elérte a 445 milliárd dollárt, amely messze meghaladja számos ország nemzeti összjövedelmét. A fenti tényekből következően a jelentés a legnagyobb valószínűséggel bekövetkező kockázatok között első helyre tette az erőszakos konfliktusok által kikényszerített migrációt. A legnagyobb károkozással járó kockázatok között a klímaváltozás hatásaihoz való alkalmazkodás kudarca foglalta el az első helyet.

A globális kockázatok közötti kölcsönös kapcsolatok tekintetében három csoport öszszefüggésrendszere emelkedett ki a felmérések során vizsgált 29 kockázat közül. Az első csoportot a természeti környezettel kapcsolatos kockázatok alkotják. Idetartozik az alkalmazkodás kudarca a klímaváltozáshoz, a szélsőséges időjárási események, a természeti

\footnotetext{
22 The Global Risks 2015, [online], 2015, World Economic Forum, 14. o. Forrás: Weforum.org [2018. 10. 31.$]$

23 Uo., 15.

24 Uo., 5-6.
} 
katasztrófák, a biodiverzitás csökkenése, a víz- és az élelmiszerhiány. A második csoport a geopolitikai kockázatok együtteseként jellemezhetö, amelynek elemei a mélyülö társadalmi instabilitás, a konfliktusok által kiváltott nagyarányú migráció, az államok válsága vagy összeomlása és az államok közötti konfliktusok. A harmadik csoport a technológiai fejlődéssel hozható összefüggésbe, amelynek elemei a technikai fejlődés esetleges káros következményei, a kritikus infrastruktúra összeomlása, a számítógépes rendszereket ért támadások, a tömeges adatlopás és az adatokkal való visszaélés. ${ }^{25}$

A Világgazdasági Fórum 2016-ban elemezte első alkalommal a globális kockázatok hatását a nemzetközi biztonságra. A nemzetközi biztonság fogalmát az alábbi definícióban határozta meg: „A nemzetközi biztonság állami vagy nem állami szereplők által egyénileg, vagy kollektívan foganatosított intézkedésekre utal, amely a határokon túlról származó fenyegetésekkel szemben biztosítja az integritást és a túlélést." ${ }^{26}$ A nemzetközi biztonsági helyzet iránti érdeklődést a geopolitikai kockázatok előtérbe kerülése indokolta. A 21. század második évtizedének közepére nyilvánvalóvá vált, hogy a globalizáció eredményeként létrejött gyors gazdasági növekedés jelentősen átalakította a globális gazdasági hatalmi egyensúlyt, és ez a hagyományos nagyhatalmi versengés kiújulásához és globális bizonytalansághoz vezetett. ${ }^{27}$

A nemzetközi biztonság története szorosan kapcsolódik a technológiai innovációk történetéhez. A jelenleg zajló Negyedik Ipari Forradalom hatásai és következményei figyelmeztetésként szolgálnak erre a kapcsolatra. Az új technológia ma is döntő hatást gyakorol nemcsak a gazdasági fejlődésre, hanem a konfliktusok kezelésének eszközeire és módszereire is. 2016-ban a Világgazdasági Fórum éves jelentése a nemzetközi biztonságra legintenzívebben ható tényezőket az alábbiakban határozta meg:

- Technológiai innováció: kihívásokat és új lehetőségeket egyaránt teremt.

- Források és a klímaváltozás menedzselése: növekszik a feszültség a forrásokhoz való hozzáférésért folytatott versengés miatt.

- Hatékony kormányzás: korrupció, a transzparencia hiánya és a jog uralmának gyengesége korlátozza a fejlődést és destabilizálja a társadalmat.

- Geostratégiai versengés: az eltolódások a gazdasági és politikai hatalomban és a kölcsönös bizalom gyengülése versengésre ösztönzi a nagyhatalmakat befolyásuk növelése érdekében, amely gyakran versengő érdekszférák kialakulásához vezet.

- Demográfiai változások: az országok egy része a gyors népszaporulattal és a fiatal korösszetétellel, más része elöregedő népességgel vagy bevándorlók beáramlásával néz szembe.

- Társadalmi kohézió és bizalom: jövedelmi egyenlőtlenség, társadalmi elszigeteltség, bizalmatlanság és marginalizáció veszélyezteti a társadalmi stabilitást.

- Hibrid és aszimmetrikus fenyegetések: a fokozódóan összekapcsolt világban komplexebb fenyegetések és nehezen azonosítható ellenfelek jelennek meg. ${ }^{28}$

\footnotetext{
5 The Global Risks Report 2016, [online], 2016, World Economic Forum, 6-7. o. Forrás: Weforum.org [2018. 10. 31.]

Uo., 24.

Uo., 28.

Uo., 29.
} 
2017-ben a korábbi éveknél hangsúlyosabban szerepeltek a davosi fórum napirendjén a növekvő jövedelmi és vagyoni különbségek, amelyek hatására fokozódott a társadalmak gazdasági polarizációja és politikai megosztottsága. Számos szakértő erre a hosszú távú folyamatra utaló jelet vélt felfedezni Trump elnök megválasztásában és Nagy-Britannia állampolgárainak döntésében az EU-ból történő távozásról. A politikai elégedetlenség, a gazdasági és politikai elitekkel való szembenállás jelei azonban az egész világon tapasztalhatók, amelyhez hozzájárulhatott a gazdasági növekedés elmaradása a várakozásoktól, valamint a felgyorsult technikai fejlődéssel való lépéstartás nehézségei. A sokasodó globális társadalmi, gazdasági, politikai, technológiai és környezeti problémák nyomasztó következményeire és a megoldásukra irányuló erőfeszítések összetettségére való tekintettel a jelentés felvetette a piaci kapitalizmus reformjának gondolatát. ${ }^{29}$

Első alkalommal tette vizsgálat tárgyává a demokrácia jövőjét a nyugati társadalmakban. A jövedelem- és vagyonelosztás növekvő egyenlőtlenségei politikailag romboló hatást gyakorolnak világszerte. Mivel a gazdasági és társadalmi folyamatokat egyre inkább globális szinten határozzák meg, növekszik az elégedetlenség a nemzeti kormányokkal szemben a stabilitás és a pénzügyi biztonság hiánya miatt. A jelentés idézi a Dani Rodrik amerikai közgazdász által alkotott fogalmat a demokrácia, a nemzeti szuverenitás és a hiperglobalizáció összefüggéséről. A Rodrik-féle „trilemma”-fogalom szerint a három fontos politikai cél közül egy időben legfeljebb csak kettő érhető el. A hiperglobalizáció és a demokrácia együttes preferenciája a nemzetállami szuverenitás feladásához vezet. Ha a nemzetállami szuverenitást választjuk a demokráciával párosítva, nem követhetjük a hiperglobalizációt. A nemzetállami szuverenitás és a hiperglobalizáció kombinációja pedig kizárja a demokráciát. ${ }^{30} \mathrm{~A}$ jelentés szerint az Egyesült Államokban és Európában zajló folyamatok a demokrácia és a nemzeti szuverenitás preferenciája irányába mutatnak. ${ }^{31}$

A demokráciát veszélyeztető tényezőket három csoportban foglalta össze a 2017. évi fórumra készített jelentés.

1. A gyors gazdasági és technológiai változás. Adatok bizonyítják, hogy a globalizáció hozzájárult a gazdasági növekedéshez és a szegénység csökkentéséhez. Ugyanakkor tény, hogy a javak fokozódó egyenlőtlen elosztása miatt hozzájárult az elitellenes érzelmek erősödéséhez. Az egyik szélsőséges példa szerint az Egyesült Államokban 2009-2012 között a lakosság leggazdagabb 1\%-ának 31\%-kal, a többi 99\%-nak ezzel szemben csak $0,5 \%$-kal nőtt a jövedelme. ${ }^{32}$

2. A mélyülő társadalmi és kulturális polarizáció. A nemzeti identitásnak, a kulturális értékeknek és az etnikai eredetnek nagy szerepe volt az elitellenes populizmus megjelenésében. Még a viszonylagosan homogén népességgel és stabil jóléti rendszerrel rendelkező országokban is megjelentek a kulturális megosztottság jelei, például az olyan új társadalmi értékek befogadásával kapcsolatban, mint a társadalmi nemek és a szekularizmus.

\footnotetext{
The Global Risks Report 2017, [online], 2017, World Economic Forum, 6. o. Forrás: Weforum.org [2018. 10. 31.]

RoDric, Dani: A globalizáció paradoxona. A demokrácia és a világgazdaság jövője. Corvina, Budapest, 2014, 254. o.

31 The Global Risks Report 2017, i. m., 13.

32 Uo., 23.
} 
3. A harmadik tényező az „igazság utáni” (post-truth) politikai vita. A demokratikus társadalmak kulturális polarizációját súlyosbította az a változás, amely a hírek és információk termelésében, terjesztésében és megosztásában bekövetkezett. A 2016-os amerikai elnökválasztás után nagy vita alakult ki a „hamis hírek” (fake news) alkalmazásáról a médiában. Az Oxford English Dictionary az év szavaként fogadta be a „posttruth” (igazság utáni) szót. A jelentését így határozta meg: „olyan körülményeket jelöl, ahol az objektív tények kevésbé hatékonyak, mint az érzelmekre és személyes hiedelmekre való hivatkozás a közvélemény formálásában”. A demokrácia alapvető feltétele a szólásszabadság és a vélemények szabad ütköztetése. A demokratikus folyamatban zajló vita feltételezi, hogy a felek kölcsönösen jóhiszemünek tekintik egymást és érvelésüket a tényekre alapozzák. A média azonban egyre kevésbé szolgáltat megbízható tényeket az ilyen vitákhoz, mert nem az objektív tények közvetítése, hanem a közvélemény érzelmeinek és hiedelmeinek való megfelelés az elsődleges célja. A következmény a növekvő megosztottság és szembenállás a társadalom különböző csoportjai között. ${ }^{33}$

A 2018-as fórumra készített dokumentum, utalva a korábbi évek elemzéseire, megállapította, hogy a klímaváltozással és az információs rendszerek biztonságával kapcsolatos kockázatok jelentősen növekedtek. A szélsőséges időjárási események első helyre kerültek mind a bekövetkezés valószínüségét, mind a pusztító hatás nagyságrendjét ábrázoló skálán. Ugyanakkor a gazdasággal kapcsolatos kockázatok csökkentek, mivel határozottabban jelentkeztek a válságból való kilábalás jelei. A biztató rövid távú fejlemények ellenére továbbra is aggodalomra adnak okot a globális gazdasági rendszer olyan problémái, mint a folyamatos feszültség a pénzügyi rendszerben, az automatizálás ma még beláthatatlan hatásai és a protekcionista politikák erősödése. ${ }^{34}$

Új elemként jelent meg a 2018. évi Davosi Fórumon a figyelmeztetés egy olyan komplex kockázatra, amely több globális rendszer egyidejü összeomlását okozhatja. A korábbi évek során az egyes jól elkülöníthető kockázatok valószínűségét és lehetséges hatásait vizsgálták. Az ökoszisztéma gyorsuló pusztulása, az információs hálózatok elleni fenyegetések fokozódása és a globális pénzügyi rendszer állandósuló feszültségei arra késztették a jelentés készítőit és a fórum résztvevőit, hogy ne hagyják figyelmen kívül azt a lehetőséget, hogy az összeomlás egyidőben több rendszerben is bekövetkezhet. A változások felgyorsulásával a több globális rendszert egyszerre érintő összeomlás veszélye növekszik. ${ }^{35}$

A komplex kockázatokkal szemben növekedett az államok és a nemzetközi rendszer sebezhetősége. A világ geopolitikai helyzetéről készített elemzésből azonban az olvasható ki, hogy az államok viszonyaiban nem tapasztalhatók a váratlan helyzetekre történő felkészülés határozott jelei. A jelentés megállapítja, hogy a világ a multipolaritás mellett multikonceptuálissá is vált. Mára eltüntek a hidegháború vége után egy ideig még idézett és általánosan alkalmazott olyan koncepciók, mint a „washingtoni konszenzus” vagy az „új világrend”, amelyek alkalmat adtak az államok számára, hogy közös normákról és intézményekröl

33 Uo., 24.

34 The Global Risks Report 2018, [online], 2018, World Economic Forum, 6-7. o. Forrás: Weforum.org [2018. 10. 31.]

35 Uo., 15-16. 
beszéljenek. Általános következmény a feszültségek növekedése és az államközi kapcsolatok zavarai, amelyek rövid távon a gazdaság és a kereskedelem területén a legkritikusabbak. Az állam jövőjével kapcsolatos posztmodern nézetek lekerültek a napirendröl, és a hangsúly az állam hatalmának elsődlegességére helyeződik, amelynek következményei vannak az üzleti életre és a civil társadalomra.

$\mathrm{Az}$ „erős állam” koncepció túlmutat a belpolitikán, érinti a nemzetközi kapcsolatokat, és a legkritikusabb hatást a nagyhatalmak viszonyában válthatja ki, különösen olyan helyzetekben, amikor gyengül a kölcsönös bizalom és a kapcsolatokat szabályozó normák tisztelete erodálódik. A gazdaságilag és katonailag legerősebb államok az ilyen szituációkat kihasználhatják vélt vagy valós veszteségeik vagy sérelmeik kompenzálására. A globalizáció hatásaként veszteséget szenvedett országok az „erös állam” koncepcióját felhasználva protekcionista kereskedelempolitikával próbálják kompenzálni veszteségeiket. A nemzetközi rend és a szabályok tiszteletének fellazulása különösen a kis államok számára káros, mivel megbízható normák és szabályok hiányában az ő lehetőségeik korlátozottabbak érdekeik érvényesítésére.

A globalizáció felfelé ívelő szakaszában általános optimizmus uralkodott a gazdasági integráció jótékony hatásait illetően. Mára azonban a kölcsönös előnyökbe vetett bizalom meggyengült, mert bebizonyosodott, hogy a globalizációnak egyaránt vannak nyertesei és vesztesei. Ez a felismerés érvényes mind a nemzetközi rendszer szintjén az államokra, mind az államokon belül a különböző társadalmi csoportokra. A vagyoni és jövedelmi egyenlötlenségek az országok között növelték a feszültséget és a konfliktusok lehetőségét a nemzetközi rendszer szintjén, az országokon belül pedig hozzájárultak a szociális és politikai feszültségekhez és a társadalom megosztottságához. A nagy kérdés az, hogyan lehet kezelni az együttmüködést igénylő komplex globális kockázatokat, amelyek közül kiemelkedik az éghajlatváltozás, a kiberbűnözés, valamint a nemzetközi kereskedelem és a nemzetközi pénzügyek bizonytalanságai. ${ }^{36}$

A 2019. januári Davosi Fórumon mind a globális kockázatok valószínűsége, mind potenciális romboló hatása tekintetében a klímaváltozással kapcsolatos kockázatok foglalták el a vezető pozíciókat. Az előfordulás valószínűségének skáláján a szélsőséges időjárási események, az éghajlat változásaihoz való adaptáció kudarca és a természeti katasztrófák foglalták el az első három helyet. A negyedik helyen a tömeges adatlopás, az ötödik helyen az információs rendszerek elleni támadások szerepeltek. A nukleáris háború már harmadik éve az első helyet foglalta el a potenciális romboló hatás rangsorában. Az előfordulás valószínüsége azonban továbbra is a legalacsonyabb az összes kockázat között. 2018 óta a potenciális romboló hatás skáláján a nukleáris háborút a klímaváltozással összefüggésbe hozható kockázatok követik. A globális kockázatok elemzése történetének legutóbbi évtizedét áttekintve megállapíthatjuk, hogy a globális gazdasággal kapcsolatos kockázatok kezdeti dominanciája után fokozatosan előtérbe kerültek a társadalompolitikai, a klímaváltozással és az információs biztonsággal kapcsolatos kockázatok.

A 2019-es fórum is vizsgálta a kockázatok közötti kölcsönös kapcsolatok erősségét. A szakértői vélemények szerint a legkritikusabb kapcsolat egyrészt a klímaváltozáshoz való

36 Uo., 37-40. 
alkalmazkodás sikere vagy kudarca, másrészt a szélsőséges időjárási események között fedezhető fel. Egy következő fontos kapcsolat a kibertámadások és a kritikus információs infrastruktúra összeomlása. Végül egy nagyobb, egymással összefüggő és egymást kölcsönösen erősítő tényezőcsoportot alkot a fokozódó társadalmi instabilitás, a nemzeti kormányzás kudarca, az összeomló állam, a munkanélküliség, az államok közötti konfliktus és a tömeges migráció. ${ }^{37}$

A globális kockázatok erősödése és romboló potenciáljuk növekedése indokolná a közös akarat és cselekvőképesség létrehozását a nemzetközi rendszer szereplői részéről. A jelentés szerint azonban ennek az ellenkezője történik: erősödik a megosztottság az államok között és növekszik a polarizáció a társadalmakban. 2019-ben a negatív tendenciák folytatására lehet számítani. Várhatóan növekszik a nagyhatalmak közötti gazdasági konfrontáció, amelynek egyik következménye a globális gazdasági növekedés lelassulása. Az IMF számításai szerint a globális GDP-növekedés a 2018-as 2,4\%-os szintről 2019-ben 2,1\%-ra csökken. Figyelmet érdemlő sebezhetőséget jelent a nemzetközi gazdasági rendszerben a globális adósságállomány, amely sokkal magasabb, mint 2008-ban, a pénzügyi válság kirobbanása előtt volt: jelenleg a globális GDP 225\%-át teszi ki. ${ }^{38}$

A társadalmi és politikai instabilitás, mint a növekvő jövedelmi és vagyoni különbségek egyik következménye visszatérően szerepelt a globális kockázatok között. A 2019. évi jelentés első alkalommal tett említést arról, hogy a szociális feszültségek forrásainak keresése, valamint a gazdasági és pénzügyi problémák megoldására irányuló törekvés ráirányította a figyelmet Adam Smith 18. századi angol közgazdász The Theory of Moral Sentiments (Az erkölcsi érzelmek elmélete) és a Wealth of Nations (A nemzetek gazdagsága) címü müveire. ${ }^{39}$ Stanley L. Brue amerikai gazdaságtörténész a következőképpen jellemzi Adam Smith két alapmüvének fö mondanivalóját: „A két mü a láthatatlan kéz vagy a természetes harmónia segítségével összhangot teremt az egyén társadalmi érdekei és az individuális jogai, mint az igazsághoz való jog között. A Moral Sentiments-ben a szimpátia és a jóakarat korlátozza az önzést; a Wealth of Nations-ben a verseny a közjóba csatornázza a gazdasági önérdeket." ${ }^{40}$ A globalizáció társadalmi következményeinek elemzése pontosan arra hívja fel a figyelmet, hogy a gazdasági önérdeket egyre kevésbé sikerül a közjóba csatornázni.

$\mathrm{Az}$ új kihívások és egyre fenyegetőbb komplex kockázatok fényében a korábbiaknál határozottabban merült fel a globális kapitalizmus újragondolásának szükségessége. A 2019-es jelentés egy másik újdonsága a társadalmak érzelmi és mentális állapotát vizsgáló kutatások eredményeinek ismertetése. A Gallup közvélemény-kutató intézet adatai szerint a harag egyre inkább a kor meghatározó érzelmi állapotává válik. A WHO adatai szerint a világon 700 millió ember mentális rendellenességtől szenved. 1990 és 2013 között a depressziós betegek száma 54\%-kal nőtt. A magas jövedelmű országokban a jövedelmi és vagyoni egyenlőtlenségek összefüggésbe hozhatók a növekvő mentális egészségi problémákkal. ${ }^{41}$

\footnotetext{
The Global Risks Report 2019, [online], 2019, World Economic Forum, 5-8. o. Forrás: Weforum.org [2019. 02. 20.] 
A World Economic Forum és a Harvard School of Public Health Research kutatási eredményei szerint a mentális rendellenességek közvetett költsége (termelékenységcsökkenés, korai nyugdíjazás stb.) 2010-ben 2,5 billió dollár volt, amely kétszerese a közvetlen kezelési költségeknek. A gazdasági veszteségeken túl a harag és a düh intenzitásának növekedése a demokráciákban is szélsőséges politikai erőket juttathat hatalomra. Az empátia és alapvető erkölcsi normák hiánya miatt fokozódó nyugtalanságot és feszültségeket a törvények és szabályok sokaságával sem lehet ellensúlyozni. ${ }^{42}$

\section{Összefoglalás}

Két évtized globális trendjeinek és kockázatainak áttekintése lehetővé teszi, hogy a változások iránya és dinamikája segítségével képet alkossunk világunk állapotáról. Mivel a forrásként felhasznált periodikusan megjelenő publikációk véleményekre épülnek, nem lehet kizárni a szubjektív megítélés lehetőségét. A valóságostól lényegesen eltérő helyzetértékelés veszélyét azonban lényegesen csökkenti az a körülmény, hogy a globális problémák különböző aspektusaival foglalkozó nagyszámú nemzetközi szakértői közösség véleményére épültek mind a National Intelligence Council, mind a World Economic Forum tanulmányai. A tanulmányokban közölt megállapításokat számos elméleti szerző következtetései is alátámasztják. Ezenkívül a nemzetközi gazdaság, a nemzetközi politika, a kormányzás problémái és a társadalmakban folytatott viták elégséges tényt és adatot szolgáltatnak, amelyek összevethetők az elmúlt két évtized globális folyamataival kapcsolatos megállapításokkal.

A World Economic Forum „Global Risks” tanulmánysorozata szemléletesen mutatja be, hogyan követte a szakértők véleménye évről évre a kockázatok fontosságának, valószínűségének, potenciális romboló hatásának és összefüggésrendszerének átalakulását. A 2019. évi Davosi Fórumra készített jelentés figyelemreméltó újdonsága a társadalmak érzelmi és pszichológiai állapotára vonatkozó kutatások ismertetése. Az egyértelműen romló állapot okait kutatva arra a következtetésre jut, hogy a globalizáció eredményeiből való szélsőségesen egyenlőtlen részesedés okozta frusztráció és harag tekinthető a deviáns magatartási formák egyik fó okának. A globális gazdaság és a technológiai haladás okozta társadalmi problémák tanulmányozásának fontossága a davosi találkozó panelvitáiban is felmerült. Az egyik panel résztvevői felvetették, hogy a korábbi időszakok technikai forradalmait intenzív társadalmi mozgások követték. A jelenleg zajló negyedik ipari forradalommal párhuzamosan időszerü lenne foglalkozni a negyedik társadalmi forradalommal is. ${ }^{43} \mathrm{~A}$ társadalmak fokozatosan romló állapotára világított rá Guy Standing angol politikatudós egy 2016-ban Prágában tartott elöadásában. A társadalmak polarizációját elemezve egy új társadalmi osztály megjelenését vizionálta, amelynek fő jellemzője a tartós munkalehetőségek és a biztos jövedelmek hiánya miatt kialakuló létbizonytalanság. Az új osztály, amelyre az előadó - az angol precarious [bizonytalan] és proletariat [proletariátus] szavak egyesíté-

\footnotetext{
Uo., 41 .

43 A „Fourth Social Revolution”? c. panelvita a Davosi World Economic Fórumon, 2019. január 25-én, [online], 2019.01. 25. Forrás: Weforum.org [2019. 02. 20.]
} 
sével keletkezett, a szociológiában és a közgazdaságtanban is meghonosodott - „precariat” megnevezéssel hivatkozik, létszámában folyamatosan növekszik, és a destabilizáció fő tényezőjévé válik a társadalmakban. ${ }^{44}$

\section{FELHASZNÁLT IRODALOM}

A „Fourth Social Revolution”? [online], 2019. 01. 25. Forrás: Weforum.org [2019. 02. 20.]

Brue, Stanley L.: The Evolution of Economic Thought. Harcourt Brace College Publishers, Orlando FL, 1994

Global Trends 2030: Alternative Worlds, [online], 2012. 12., National Intelligence Council, 9-15. o. Forrás:

Globaltrends2030.files.wordpress.com [2018. 10. 31.]

Global Trends: Paradox of Progress, [online], 2017. 01., National Intelligence Council, 8-10. o. Forrás:

Globaltrends2030.files.wordpress.com [2018. 10. 31.]

Rodric, Dani: A globalizáció paradoxona. A demokrácia és a világgazdaság jövője. Corvina, Budapest, 2014

Standing, Guy: What is the Precariat? [online], 2017. 02. 26., TEDx Talks. Forrás: Youtube.com [2019. 02. 20.]

The Global Risks Report 2016, [online], 2016, World Economic Forum, 6. o. Forrás: Wef.ch [2018. 10. 31.]

The Global Risks 2013, [online], 2013, World Economic Forum, 8-15. o. Forrás: Weforum.org [2018. 10. 31.]

The Global Risks 2014, [online], 2014, World Economic Forum, 9-25. o. Forrás: Weforum.org [2018. 10. 31.]

The Global Risks 2015, [online], 2015, World Economic Forum, 14. o. Forrás: Weforum.org [2018. 10. 31.]

The Global Risks Report 2016, [online], 2016, World Economic Forum, 6-7. o. Forrás: Weforum.org [2018. 10. 31.]

The Global Risks Report 2017, [online], 2017, World Economic Forum, 6. o. Forrás: Weforum.org [2018. 10. 31.]

The Global Risks Report 2018, [online], 2018, World Economic Forum, 6-7. o. Forrás: Weforum.org [2018. 10. 31.]

The Global Risks Report 2019, [online], 2019, World Economic Forum, 5-8. o. Forrás: Weforum.org [2019.

02. 20.] 